\title{
KORELASI PENGUASAAN KOSAKATA DENGAN KETERAMPILAN BERBICARA SISWA DALAM BAHASA INGGRIS
}

\author{
Adhityo Kuncoro \\ Program Studi Teknik Informatika, Universitas Indraprasta PGRI \\ Email: adhityokuncoro@yahoo.com
}

\begin{abstract}
Abstrak
Penelitian ini bertujuan untuk membuktikan secara ilmiah bahwa penguasaan kosakata mempunyai korelasi dengan keterampilan berbicara. Penelitian ini menggunakan metode survey yang dilakukan di tiga kelas Universitas Indraprasta PGRI yang berisi mahasiswa tingkat (semester) dua. Jumlah responden adalah 40 mahasiswa dari dua kelas yang berbeda. Data penelitian ini diperoleh melalui tes tertulis yang kemudian diolah dengan program SPSS 2.0 dan menggunakan analisis regresi dan korelasi. Hasil penelitian ini menunjukkan bahwa adanya pengaruh yang signifikan penguasaan kosakata terhadap keterampilan berbicara terbukti dari nilai sig $=0,000$ (nilai sig $<0,05)$ dan $\mathrm{t}_{\text {hitung }}=3,694\left(\mathrm{t}_{\text {hitung }}\right.$ lebih besar dari $\left.t_{\text {tabel }}=1,69\right)$. Berdasarkan hasil penelitian tersebut dapat disimpulkan bahwa penguasaan kosakata memiliki pengaruh/korelasi terhadap keterampilan berbicara siswa.
\end{abstract}

Kata Kunci: korelasi, kosakata, keterampilan berbicara

\begin{abstract}
The purpose of this research is to scientifically show a correlation between vocabulary mastery and speaking skill. The research, using a survey method, is performed in three classes of first semester students at Universitas Indraprasta PGRI, with 40 respondents taken from students of two different classes. The data of the research are obtained through written tests, then processed using SPSS 2.0 program and analyzed applying regression and correlation analyses. The result of the research shows a significant effect of vocabulary mastery on speaking skill as seen by the value of sig=0,000 (sig<0,05) and $t_{\text {observed }}=3,694$ $\left(t_{\text {observed }}\right.$ is more than $\left.t_{\text {table }}=1,69\right)$. Based on the result of the research, it can be concluded that vocabulary mastery has an effect on or a correlation with student's speaking skill.
\end{abstract}

Keywords: correlation, vocabulary, speaking skill

\section{Pendahuluan}

Dalam menyongsong persaingan yang bersifat global, kemampuan menggunakan bahasa Internasional merupakan salah satu aspek yang penting. Kemampuan berbahasa terutama berbahasa Inggris menjadi suatu aspek yang sangat penting dalam memperlengkapi sumber daya manusia yang akan terjun dalam dunia pekerjaan. Oleh karena itu, siswa harus dipersiapkan agar menjadi sumber daya manusia yang berkualitas tinggi dan memiliki keterampilan yang berguna terutama dalam segi kemampuan berbahasanya. Kompetensi berbahasa mencakup empat hal yaitu, menyimak, berbicara, membaca, dan menulis. Oleh karena kemampuan berkomunikasi berbahasa mencakup komunikasi lisan dan komunikasi tulisan, diperlukan keseimbangan antar kompetensi berbahasa dalam proses pembelajaran.

Kemampuan membaca, menyimak, berbicara dan menulis merupakan alat yang ampuh dalam mendukung kemampuan berpikir dan belajar. Kemampuan berbicara mendapatkan kontribusi dari aktivitas membaca. Dari aktivitas membaca, siswa akan memperoleh berbagai gagasan dan pengetahuan yang dapat digunakan sebagai bahan untuk mengembangkan teks pidato atau percakapan tentang topik tertentu. Sebagai contoh, seorang guru yang akan menyampaikan materi ajar kepada siswanya perlu memperlengkapi diri dengan membaca dari berbagai sumber yang memadai, misalnya buku teks, buku-buku lain yang terkait, media cetak, dan media-media elektronik misalnya, internet. Dengan mendapatkan informasi dari berbagai sumber tersebut, isi pidato atau percakapan akan menjadi lebih berbobot. 
Kemampuan berbicara sangat bergantung pada aktivitas input siswa (seperti membaca dan mendengar) sehingga setiap siswa memiliki kemampuan berbicara yang berbeda-beda meskipun diberikan materi yang sama pada saat kegiatan belajar mengajar. Kegiatan belajar siswa dipengaruhi oleh berbagai faktor, seperti motivasi, kematangan, hubungan siswa dengan guru, kemampuan verbal, tingkat kebebasan, rasa aman dan keterampilan guru dalam berkomunikasi. Jika faktor-faktor yang disebutkan di atas terpenuhi, maka melalui proses pembelajaran, siswa dapat memiliki pengetahuan dan kemampuan berbicara yang baik.

Dalam mengasah kemampuan berbicara diperlukan penguasaan kosakata yang memadai. Peranan kosakata sangatlah penting dalam proses pembelajaran bahasa. Kualitas dan kuantitas serta kedalaman kosakata seseorang merupakan indeks pribadi yang terbaik bagi perkembangan mentalnya. Selain itu, pengembangan kosakata merupakan pengembangan konsep tunggal yang merupakan tujuan pendidikan dasar bagi setiap sekolah atau perguruan. Semua jenjang pendidikan pada prinsipnya adalah pengembangan kosakata yang juga merupakan pengembangan konseptual. Pengembangan kosakata dipengaruhi oleh usia, jenis kelamin, kemampuan bawaan, dan status sosial. Faktor-faktor geografis juga turut mempengaruhi perkembangan kosakata.

Kosakata dapat dirangkai menjadi frasa, klausa, dan kalimat dengan menggunakan kaidah tertentu yang telah disepakati dalam suatu sistem bahasa. Rangkaian kosakata inilah yang kemudian digunakan untuk membentuk ide/gagasan yang kemudian disampaikan secara lisan saat berbicara. Oleh karena itu, keterampilan berbicara seseorang sangat bergantung pada kualitas dan kuantitas kosakata yang dimilikinya. Semakin berkualitas dan kaya akan kosakata, maka semakin besar peluang seseorang untuk menjadi terampil dalam berbicara. Penguasaan kosakata menjadi salah satu langkah awal yang perlu diperhatikan bagi pelajar.

Pelajar dapat memperluas perbendaharaan kosakata mereka melalui kegiatan membaca. Dengan bantuan internet dan sarana lainnya, pelajar bahasa dapat dengan mudah mendapatkan buku maupun bahan bacaan dalam bahasa yang mereka inginkan. Jika mereka dengan tekun mempertahankan minat membaca mereka dengan baik, maka penguasaan kosakata mereka akan membantu mereka lebih terampil dalam berbicara bahasa asing. Berdasarkan latar belakang tersebut, maka rumusan masalah dalam penelitian ini difokuskan pada pengaruh penguasaan kosakata terhadap keterampilan berbicara bahasa Inggris mahasiswa semester satu Universitas Indraprasta PGRI. Penelitian ini bertujuan untuk membuktikan secara ilmiah korelasi antara penguasaan kosakata dengan ketrampilan berbicara bahasa Inggris. Penelitian ini diharapkan dapat bermanfaat sebagai referensi kajian keilmuan untuk penelitian lain di bidang yang sama, khususnya bidang kebahasaan.

\section{Tinjauan Pustaka \\ Berbicara}

Komunikasi yang umum dilakukan oleh manusia dapat digolongkan menjadi dua bentuk, yaitu komunikasi lisan dan tulisan. Berbicara merupakan bentuk komunikasi lisan dan paling sering dilakukan oleh manusia. Berbicara adalah kemampuan yang bersifat produktif secara lisan. Secara mendalam, berbicara dapat didefinisikan sebagai sistem tanda yang dapat didengar dan memanfaatkan otot-otot serta jaringan otot manusia untuk mengkomunikasikan ide-ide melalui bunyi-bunyi artikulasi atau kata-kata untuk mengekspresikan, menyatakan serta menyampaikan pikiran, gagasan, dan perasaan. Berbicara juga dipahami sebagai bentuk perilaku manusia yang memanfaatkan faktor fisik, psikis, neurologis, semantik, dan linguistik secara ekstensif, sehingga dapat digunakan sebagai alat yang sangat penting untuk melakukan kontrol sosial (Tarigan, 2008: 16). Pengertian tersebut menunjukkan dengan jelas bahwa berbicara berkaitan dengan pengucapan kata-kata yang bertujuan untuk menyampaikan apa yang akan disampaikan baik itu perasaan, ide atau gagasan. 
Para ahli menyebutkan bahwa ada beberapa jenis bentuk dalam menyampaikan pesan, ide ataupun gagasan bergantung pada tujuan maupun fungsinya. Keraf (dalam Slamet, 2009a: 38) membedakan jenis-jenis berbicara menjadi tiga macam di antaranya, yaitu persuasif, instruktif dan rekreatif. Jenis berbicara persuasif biasanya mampu mendorong, meyakinkan, dan membuat para pendengarnya untuk bertindak. Menginginkan reaksi dari para pendengar untuk mendapatkan ilham/inspirasi atau membangkitkan emosi untuk mendapatkan persesuaian pendapat, intelektual, bahkan tindakan dari pendengar. Jenis berbicara instruktif/memberitahukan menginginkan reaksi dari pendengar berupa pengertian yang tepat. Jenis berbicara rekreatif bersifat menyenangkan dan menginginkan reaksi dari pendengar berupa minat dan kegembiraan. Sementara itu, Haryadi dan Zamzani (dalam Slamet 2009b: 38) membagi jenis-jenis berbicara menjadi dua macam, yaitu berbicara dimuka umum yang mencakup berbicara pemberitahuan, kekeluargaan, bujukan, perundingan dan berbicara pada konferensi, yang meliputi diskusi kelompok, prosedur parlementer dan debat.

Berdasarkan beberapa pernyataan tersebut dapat disimpulkan bahwa pada hakikatnya berbicara adalah ungkapan pikiran dan perasaan seseorang dalam bentuk bunyi-bunyi bahasa. Dalam konteks demikian, kemampuan berbicara bisa dipahami sebagai kemampuan mengucapkan bunyi-bunyi artikulasi atau mengucapkan kata-kata untuk mengekspresikan, menyatakan, menyampaikan pikiran, gagasan dan perasaan. Pendengar menerima informasi melalui rangkaian nada, tekanan, dan penempatan jeda yang dapat bersifat persuasif, instruktif maupun rekreatif. Jika komunikasi berlangsung secara tatap muka, aktivitas berbicara dapat diekspresikan dengan bantuan mimik dan pantonimik pembicara.

\section{Keterampilan}

Menurut Soemarjadi (2002: 1), keterampilan adalah kepandaian melakukan sesuatu pekerjaan dengan cekatan dan benar. Terampil lebih dari sekedar memahami sehingga untuk menjadi terampil diperlukan latihan-latihan praktis yang bisa memberikan rangsangan pada otak. Keterampilan menurut Subana dan Sunarti (2000: 36) juga berarti kemampuan seseorang menggunakan pikiran atau nalar yang menghasilkan perbuatan yang efisien dan efektif dalam mencapai suatu hasil tertentu.

Keterampilan mengandung beberapa unsur kemampuan, yaitu kemampuan olah pikir (psikis) dan kemampuan olah perbuatan (fisik). Robbins (2000: 494-495) mengatakan bahwa pada dasarnya keterampilan dapat dikategorikan menjadi empat, yaitu basic literacy skill, technical skill, interpersonal skill dan problem solving. Basic literacy skill adalah keahlian dasar seseorang yang pasti dan wajib dimiliki seperti, membaca, menulis, mendengar dan berbicara. Technical skill adalah keahlian seseorang dalam mengembangkan kemampuannya di bidang teknis, seperti pengoperasian komputer, menghitung secara tepat dan lainnya. Interpersonal skill adalah kemampuan seseorang dalam berinteraksi dengan orang lain baik dalam berkomunikasi maupun bekerja sama dalam suatu tim. Sedangkan problem solving adalah aktivitas seseorang dalam menggunakan logika untuk mengetahui penyebab, mengembangkan alternatif, menganalisa serta memilih bentuk penyelesaian masalah yang cocok.

\section{Keterampilan berbicara}

Keterampilan dapat didefinisikan sebagai kemampuan/kecakapan seseorang untuk menggunakan pikiran, nalar serta perbuatan dalam mengerjakan sesuatu secara efektif dan efisien. Dalam hal berbicara, seseorang dapat dikategorikan terampil jika mereka mampu berbicara dengan efektif dan efisien. Menurut Arsjad dan Mukti (1991: 87) dalam berbicara ada beberapa faktor yang menunjang keefektifan berbicara, yaitu faktor kebahasaan dan non kebahasaan. Faktor kebahasaan mencakup ketepatan dalam pengucapan bunyi, durasi, penempatan tekanan, nada bicara yang sesuai, pemilihan kata yang tepat, dan menggunakan 
kalimat yang efektif. Sedangkan faktor non bahasa mencakup kelentukan berbicara, kontak visual dengan pendengar, gerakan dan mimik yang sesuai, volume suara yang memadai, kelancaran berbicara dan penguasaan bahan.

Selain faktor bahasa dan non bahasa, keterampilan berbicara juga terdiri dari empat aspek, yaitu keterampilan sosial, semantik, fonetik dan vokal. Keterampilan sosial adalah kemampuan untuk berpartisipasi secara efektif dalam hubungan bermasyarakat. Keterampilan sosial menuntut agar kita mengetahui apa yang harus dikatakan, bagaimana cara mengatakannya, dimana mengatakannya, dan kapan untuk tidak mengatakannya. Keterampilan semantik adalah kemampuan untuk menggunakan kata-kata dengan tepat dan penuh pengertian. Untuk memperoleh keterampilan semantik maka kita harus memiliki pengetahuan yang luas mengenai makna-makna yang terkandung dalam kata-kata serta ketepatan dan kepraktisan dalam penggunaan kata-kata tersebut. Keterampilan fonetik adalah kemampuan membentuk unsur-unsur fonetik bahasa kita secara tepat. Keterampilan ini diperlukan karena turut mengemban serta menentukan persetujuan atau penolakan secara sosial. Keterampilan vokal adalah kemampuan untuk menciptakan efek emosional yang diinginkan dengan suara.

\section{Penilaian keterampilan berbicara}

Pada setiap akhir masa dalam suatu proses belajar perlu diadakan penilaian atas hasil kinerja pembelajaran. Penilaian tersebut dapat diperoleh melalui pengadaan tes yang diberikan kepada para siswa. Tes merupakan alat untuk mengukur/mengetahui kemampuan siswa dalam mengikuti proses pembelajaran yang telah berlangsung. Pada prinsipnya, ujian/tes keterampilan berbicara siswa tersebut difokuskan pada tes praktik berbicara. Penilaian dalam tes keterampilan berbicara tersebut terdiri dari dua hal, yaitu faktor kebahasaan dan non kebahasaan (Nurgiyantoro, 1995a: 152). Penilaian dari faktor kebahasaan meliputi, pengucapan/pelafalan, tata bahasa/struktur kebahasaan dan kosakata/perbendaharaan kata. Sedangkan penilaian dari faktor non kebahasaan menurut Nurgiyantoro (1995b: 152) meliputi ketenangan sewaktu berbicara, volume suara yang sesuai, kelancaran dalam berbicara, dan pemahaman materi yang disampaikan.

\section{Penguasaan kosakata}

Kosakata mempunyai peranan yang penting dalam kehidupan sehari-hari, terutama dalam kegiatan komunikasi di masyarakat dan dalam proses pembelajaran di sekolah. Penguasaan kosakata yang cukup akan memperlancar pemahaman siswa terhadap materi pelajaran yang diberikan oleh guru. Kata dalam bahasa Yunani kuno disebut juga lexicon. Beberapa ahli mendefinisikan kosakata sebagai perbendaharaan kata dalam suatu bahasa. Menurut Chaer (2009: 9) menyebutkan bahwa istilah leksikon lazim digunakan untuk mewadahi konsep kumpulan leksem dari suatu bahasa, baik kumpulan secara keseluruhan maupun secara sebagian. Leksikon merupakan komponen bahasa yang memuat semua informasi tentang makna dan pemakaian kata dalam suatu bahasa.

Menurut Keraf (2007: 21), kosakata merupakan alat penyalur ide/gagasan yang berarti bahwa semakin banyak kosakata yang dikuasai maka semakin banyak dan semakin lancar gagasan tersebut disampaikan. Nurgiyantoro (2001a: 213) menyatakan bahwa penguasaan kosakata adalah kemampuan seseorang untuk mengenal, memahami, dan menggunakan katakata dengan baik dan benar, dengan mendengar, berbicara, membaca, dan menulis. Kemampuan untuk memahami diwujudkan dalam kegiatan membaca dan menyimak, sedangkan kemampuan mempergunakan diwujudkan dalam kegiatan menulis dan berbicara. Mengenal kata adalah memperoleh kata-kata baru dari hasil mendengarkan atau dari hasil membaca. Hakikat memahami kata-kata adalah memperoleh kosakata baru, mengerti kata dan artinya serta memahami keterkaitan kata dan konsep yang diawali kata-kata tersebut. Menurut Djiwandono (1996a: 42) dalam kegiatan berkomunikasi kosakata merupakan unsur 
yang amat penting. Makna suatu wacana sebagai bentuk penggunaan bahasa sebagian besar ditentukan oleh kosakata yang digunakan dalam pengungkapannya. Dengan demikian, apabila seorang anak kurang memiliki kemampuan dalam menguasai kosakata, anak tersebut akan mengalami kesulitan dalam memahami suatu bahasa. Pada anak, penguasaan kosakata tidak cukup hanya memahami saja, tetapi hal itu juga harus meliputi kemampuan penggunaan kosakata tersebut dalam kegiatan berkomunikasi.

Nurgiyantoro (2001b: 196) mengemukakan bahwa kemampuan untuk memahami kosakata merupakan penguasaan reseptif, sedangkan kemampuan mempergunakan kosakata merupakan penguasaan produktif. Penguasaan reseptif terlihat ketika anak mampu melakukan kegiatan membaca dan menyimak, sedangkan penguasaan produktif terlihat dalam kegiatan berbicara dan menulis. Purwo (dalam Yunisah, 2007: 11) mengemukakan bahwa penguasaan kosakata merupakan ukuran pemahaman seseorang terhadap kosakata suatu bahasa dan kemampuannya menggunakan kosakata tersebut baik secara lisan maupun tertulis. Penguasaan kosakata merupakan bagian dari penguasaan bahasa sebab jika seseorang menguasai bahasa berarti orang tersebut menguasai kosakata. Penguasaan kosakata menjadi sangat penting karena ide/gagasan akan mudah dipahami jika diungkapkan dengan pilihan kata yang tepat. Dengan memiliki penguasaan kosakata yang baik, kemampuan berbicara dapat lebih berkembang.

\section{Penilaian penguasaan kosakata}

Tes kosakata merupakan bagian dari tes kemampuan kebahasaan. Tes ini dilakukan untuk melakukan penilaian atau memperoleh informasi tentang hasil belajar bahasa yang dicapai oleh anak didik, yang secara tidak langsung akan memberikan pula informasi tentang berbagai segi penyelenggaraan pengajaran (Djiwandono, 1996b: 6). Tes kosakata dilakukan untuk mengukur kemampuan anak didik, baik yang bersifat reseptif maupun yang bersifat produktif. Dengan demikian, dalam tes kosakata antara kemampuan reseptif dan kemampuan produktif harus saling berkaitan antara satu dengan yang lainnya.

Menurut Nurgiyantoro (2001c: 196) dalam tes kosakata ada dua hal yang perlu diperhatikan, yaitu: (a) pemilihan kosakata yang akan diteskan dan (b) pemilihan bentuk dan cara pengetesan khususnya yang menyangkut penyusunan tes yang sesuai dengan tingkatantingkatan aspek kognitif tertentu. Tingkatan tes penguasaan kosakata dalam penelitian ini mengacu pada tingkatan kognitif yang biasa disebut Taksonomi Bloom. Tingkatan ini terdiri dari enam tingkatan yaitu tingkat pengetahuan/ingatan (C1), tingkat pemahaman (C2), tingkat aplikasi (C3), tingkat analisis (C4), tingkat evaluasi (C5) dan tingkat kreativitas (C6). Nurgiyantoro (2001d: 209) menyatakan bahwa untuk tes penguasaan kosakata tingkatan kognitif yang dipakai sampai pada tingkat analisis (C4). Berdasarkan pendapat tersebut tes penguasaan kosakata dalam penelitian ini menggunakan empat tingkatan yaitu tingkat ingatan/pengetahuan (C1), tingkat pemahaman (C2), tingkat aplikasi (C3) dan tingkat analasis (C4). Tes kosakata tingkat kognitif yang tinggi (C5 dan C6) tidak digunakan dalam penelitian ini karena tes dengan tingkat kognitif tersebut menuntut kemampuan yang lebih dalam dan sekaligus dapat menilai proses berpikir. Selain itu, tes kosakata tingkat C5 dan C6 lebih tepat apabila digunakan untuk tes bentuk esai.

\section{Metodologi Penelitian}

Penelitian ini dilakukan di dua kelas mahasiswa tingkat satu Universitas Indraprasta PGRI pada tahun 2015. Teknik pengumpulan data dilakukan dengan cara memberikan tes tertulis dan kemudian data tersebut diolah dengan analisis regresi dan korelasi.

\section{Analisis regresi}

Sudjana (dalam Pratomo dan Astuti, 2015: 2) mengatakan bahwa analisis regresi adalah cabang ilmu statistika yang mempelajari bentuk hubungan fungsional suatu variable 
(variabel bebas/predictor) terhadap variabel lain (variabel respon). Regresi dibagi menjadi dua, yaitu analisis linier sederhana dan analisis linier berganda. Analisis regresi linier adalah jika hubungan persamaan anatar variabel bebas $(\mathrm{X})$ dan variabel $(\mathrm{Y})$ searah dan membentuk sebuah pola garis lurus. Jadi, jika nilai variabel (X) meningkat, maka nilai variabel (Y) juga meningkat. Begitu pula sebaliknya, jika antara $(\mathrm{X})$ dan $(\mathrm{Y})$ mengalami hubungan yang negatif (Sudjana, 2006: 356). Berikut adalah rumusan dari regresi linier:

Keterangan:

$$
Y=a+b x
$$

$Y=$ Subjek dalam variabel dependen (tidak bebas) yang diprediksikan.

$X=$ Subjek pada variabel independen (bebas) yang mempunyai nilai tertentu.

$a=$ Parameter intercept.

$b=$ Parameter koefisien regresi variabelbebas.

(Sumber: Sugiyono, 2010: 188)

\section{Analisis korelasi}

Analisis korelasi digunakan untuk mengetahui keeratan hubungan antara dua variabel dan untuk mengetahui arah hubungan yang terjadi. Teknik analisis korelasi Product Moment Pearson termasuk dalam teknik statistic parametric yang menggunakan data interval dengan persyaratan tertentu. Pemilihan data dilakukan secara acak namun tetap berdistribusi normal. Menurut Sugiyono (2008: 274), persamaan korelasi Pearson dinyatakan dalam rumus:

$$
r=\frac{n(\Sigma x i y i)-(\Sigma x i)(\Sigma y i)}{\sqrt{\left.\left\{\left(n \Sigma x i^{2}\right)-(\Sigma x i)^{2}\right\}\left\{\left(n \Sigma y i^{2}\right)-(\Sigma y i)^{2}\right)\right\}}}
$$

Adapun menurut Riduwan (2010: 98), interpretasi mengenai koefisien korelasi adalah sebagai berikut:

Tabel 1. Interpretasi Koefisien Korelasi

\begin{tabular}{cc}
\hline Interval koefisien & Tingkat hubungan \\
\hline $0,80-1,000$ & Sangat kuat \\
$0,60-0,799$ & Kuat \\
$0,40-0,599$ & Cukup kuat \\
$0,20-0,399$ & Rendah \\
$0,00-0,199$ & Sangat rendah \\
\hline
\end{tabular}

\section{Hasil dan Pembahasan}

Data survey dalam penelitian ini diambil dari 40 responden yang terdiri dari dua kelas yang berbeda dan diolah dengan bantuan komputer melalui program SPSS 2.0. Deskripsi secara statistik dari seluruh responden ditampilkan pada Tabel 2 berikut.

Tabel 2. Deskripsi Statistik Variabel Penguasaan Kosakata (X), dan Keterampilan Berbicara(Y)

\begin{tabular}{lrrr}
\hline & X & \multicolumn{1}{c}{$\mathrm{Y}$} \\
\hline $\mathrm{N}$ & Valid & 40 & 40 \\
& Missing & 0 & 0 \\
\hline Mean & 19,3500 & 17,6500 \\
Median & 19,0000 & 18,0000 \\
Mode & 17,00 & 20,00 \\
Std. Deviation & 4,20957 & 2,87830 \\
Variance & 17,721 & 8,285 \\
Skewness &, 028 &,- 119 \\
Std. Error of Skewness &, 374 &, 374 \\
Kurtosis &,- 058 &, 296 \\
Std. Error of Kurtosis &, 733 &, 733 \\
Range & 19,00 & 13,00 \\
Minimum & 9,00 & 12,00 \\
Maximum & 28,00 & 25,00 \\
\hline
\end{tabular}




\section{Analisis data variabel X (Penguasaan Kosakata)}

Berdasarkan Tabel 2 di atas, dapat kita lihat bahwa nilai maksimum dari variabel $\mathrm{X}$ adalah 28 sedangkan nilai minimumnya adalah 9 . Nilai beda maksimum dan minimum atau yang biasa disebut range/jangkauan untuk variabel $X$ adalah 19 . Nilai rata-rata/mean variabel $X$ ini adalah 19,35. Sedangkan untuk nilai median/nilai tengahnya adalah 19. Angka ini menunjukkan bahwa 50 persen siswa mempunyai nilai yang lebih kecil dari nilai median tersebut. Selain itu, perbedaan antara nilai rata-rata dan nilai tengah yang tidak begitu jauh $($ mean $=19,35$ dan median $=19)$ menunjukkan bahwa data penguasaan kosakata cukup representatif. Berdasarkan angka yang tertera pada modus, mayoritas siswa mempunyai jumlah nilai 17 untuk variabel $\mathrm{X}$.

Menurut ukuran disperse dengan ukuran standar deviasi menunjukkan bahwa variabel X memiliki nilai sebesar 4,2. Sedangkan tingkat heterogen dari variabel $\mathrm{X}$ dapat kita lihat dari angka yang tertera di kolom variance, yaitu sebesar 17,72. Kemudian jika dilihat dari distribusinya, angka statistik menunjukkan bahwa variabel $\mathrm{X}$ mempunyai distribusi menceng ke kanan yang ditandai oleh nilai skewness positif sebesar 0,028 (lihat Gambar 1). Dan jika dilihat keruncingannya atau kurtosisnya, menunjukkan bahwa variabel $\mathrm{X}$ memiliki pola distribusi yang mendatar karena nilai kurtosisnya negatif sebesar -0,058. Berikut adalah histogram data variabel X (penguasaan kosakata).

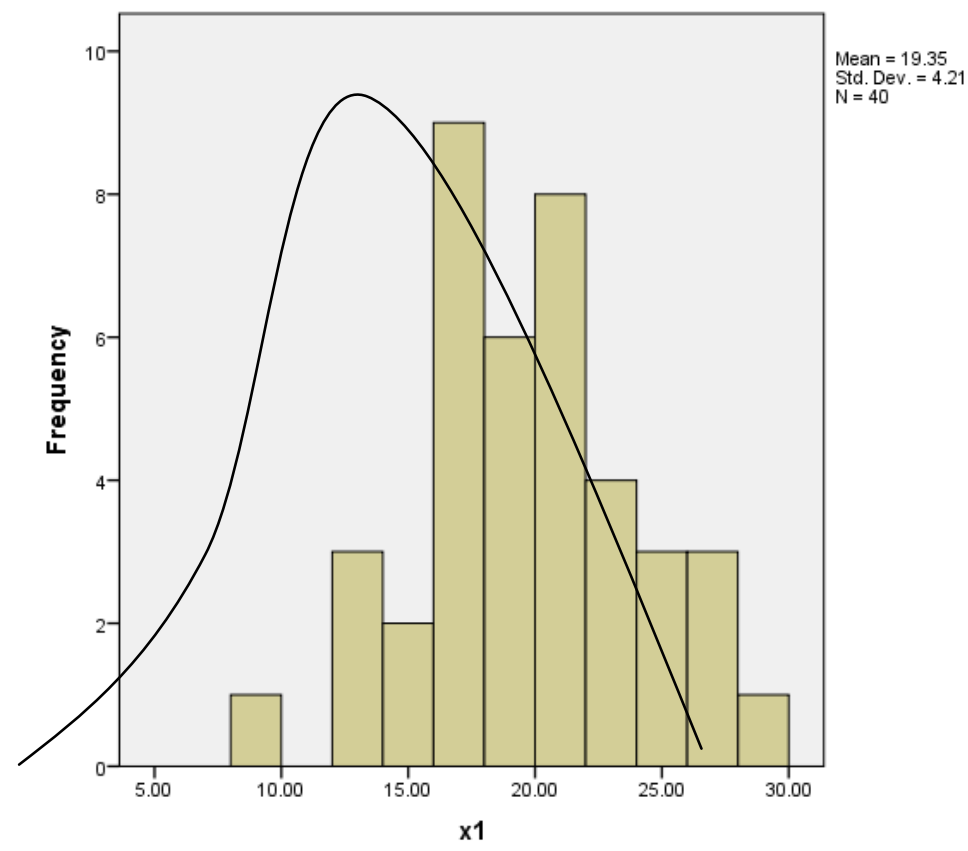

Gambar 1. Histogram Data Skor Penguasaan Kosakata pada Siswa

Dari tabel distribusi, histogram dan polygon frekuensi dapat disimpulkan bahwa data skor penguasaan kosakata dalam penelitian ini cenderung terdistribusi normal.

\section{Analisis data variabel Y (Keterampilan Berbicara)}

Berdasarkan Tabel 2 di atas, dapat kita lihat bahwa nilai maksimum dari variabel $\mathrm{Y}$ adalah 25 sedangkan nilai minimumnya adalah 12 . Nilai beda maksimum dan minimum atau yang biasa disebut range/jangkauan untuk variabel $\mathrm{Y}$ adalah 12 . Nilai rata-rata/mean variabel $\mathrm{Y}$ ini adalah 17,65. Sedangkan untuk nilai median/nilai tengahnya adalah 18. Angka ini menunjukkan bahwa 50 persen siswa mempunyai nilai yang lebih kecil dari nilai median tersebut. Selain itu, perbedaan antara nilai rata-rata dan nilai tengah yang tidak begitu jauh $($ mean $=17,65$ dan median $=18)$ menunjukkan bahwa data keterampilan berbicara cukup 
representatif. Berdasarkan angka yang tertera pada modus, mayoritas siswa mempunyai jumlah nilai 20 untuk variabel $\mathrm{Y}$.

Menurut ukuran disperse dengan ukuran standar deviasi menunjukkan bahwa variabel Y memiliki nilai sebesar 2,87. Sedangkan tingkat heterogen dari variabel $\mathrm{Y}$ dapat kita lihat dari angka yang tertera di kolom variance, yaitu sebesar 8,28. Kemudian jika dilihat dari distribusinya, angka statistik menunjukkan bahwa variabel $\mathrm{Y}$ mempunyai distribusi menceng ke kiri yang ditandai oleh nilai skewness negatif sebesar -0,11 (lihat Gambar 2). Dan jika dilihat keruncingannya atau kurtosisnya, menunjukkan bahwa variabel $\mathrm{Y}$ meruncing karena nilai kurtosisnya positif sebesar 0,29. Berikut adalah histogram data variabel $Y$ (keterampilan berbicara).

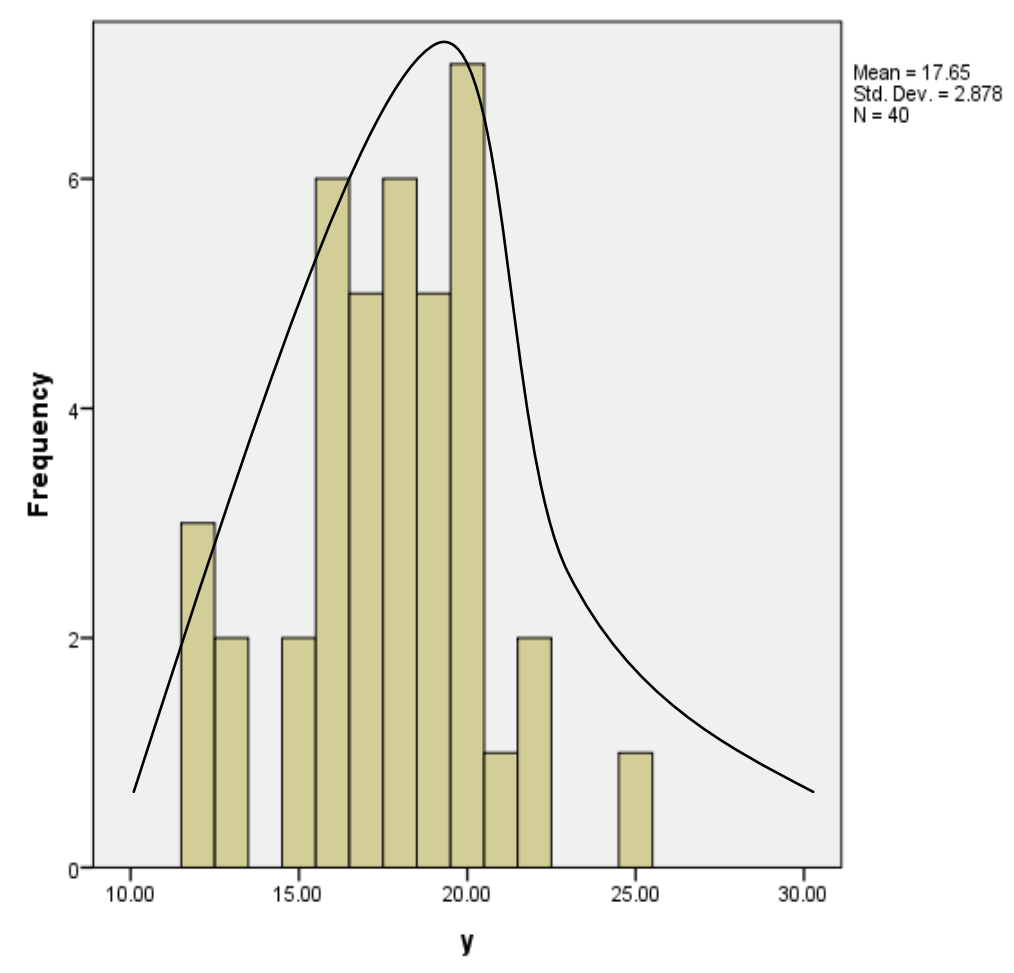

Gambar 2. Histogram Data Skor Keterampilan Berbicara Siswa

Dari tabel distribusi, histogram dan polygon frekuensi dapat disimpulkan bahwa data skor keterampilan berbicara dalam bahasa Inggris siswa dalam penelitian ini cenderung terdistribusi normal.

\section{Pengujian linieritas garis regresi}

Pengujian linieritas dalam penelitian ini digunakan hipotesis berikut:

$\mathrm{H}_{0}$ : garis regresi hubungan antara variabel $\mathrm{X}$ dan variabel $\mathrm{Y}$ linier

$\mathrm{H}_{1}$ : garis regresi hubungan antara variabel $X$ dan variabel $Y$ tidak linier

Perhitungan dilakukan dengan bantuan komputer melalui program SPSS 2.0. Sesuai dengan ketentuan yang berlaku pada program tersebut, kriteria dari normalitas data terpenuhi jika $p$ value (sig)> $0,05\left(\mathrm{H}_{0}\right.$ diterima). Jika $\mathrm{H}_{0}$ diterima maka garis regresi tersebut linier. Nilai sig adalah bilangan yang tertera pada kolom sig baris Deviation from Liniearity dalam tabel ANOVA hasil perhitungan pengujian linieritas garis regresi dengan program SPSS.

\section{Linieritas garis regresi hubungan $\mathrm{X}$ dengan $\mathrm{Y}$}

Hasil perhitungan pengujian linieritas garis regresi hubungan antara variabel $\mathrm{X}$ dengan variabel Y dapat dilihat pada Tabel 3. 
Tabel 3. Rekapitulasi Hasil Pengujian Linieritas garis Regresi Hubungan antara Variabel $X$ dengan Variabel $Y$

\begin{tabular}{|c|c|c|c|c|c|c|c|c|}
\hline \multicolumn{9}{|c|}{ ANOVA Table } \\
\hline & & & & $\begin{array}{ll}\text { Sum } & \text { of } \\
\text { Squares }\end{array}$ & $f D f$ & $\begin{array}{l}\text { Mean } \\
\text { Square }\end{array}$ & $F$ & Sig. \\
\hline \multirow{5}{*}{$y * x$} & & (Combined) & \multirow{5}{*}{ from } & 217,743 & 15 & 14,516 & 3,307 & 0,004 \\
\hline & Between & Linearity & & 125,837 & 1 & 125,837 & 28,665 & 0,000 \\
\hline & Groups & $\begin{array}{l}\text { Deviation } \\
\text { Linearity }\end{array}$ & & 91,906 & 14 & 6,565 & 1,495 & 0,187 \\
\hline & Within $G$ & & & 105,357 & 24 & 4,390 & & \\
\hline & Total & & & 323,100 & 39 & & & \\
\hline
\end{tabular}

Dari Tabel 3 di atas, kita dapat lihat bahwa nilai pada kolom Deviation from Linearity adalah 0,187 lebih besar dari 0,05 sehingga $\mathrm{H}_{0}$ diterima dan hal ini mengartikan bahwa garis regresi antara variabel $\mathrm{X}$ dan $\mathrm{Y}$ tersebut linier. Untuk membuktikan hipotesis tersebut adalah dengan memperhatikan nilai/bilangan yang tertera pada kolom $\mathrm{t}$ atau kolom sig untuk baris Penguasaan Kosakata (X) pada Tabel 3. Menurut ketentuan yang ada, kriteria signifikansi

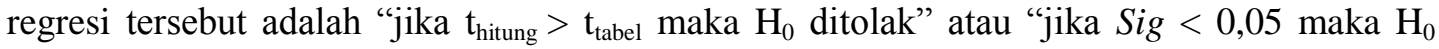
ditolak", yang berarti bahwa terdapat pengaruh yang signifikan variabel bebas $\mathrm{X}$ terhadap variabel Y. Nilai sig adalah bilangan yang tertera pada kolom sig untuk baris Penguasaan Kosakata dalam Tabel 3. Nilai $t_{\text {hitung }}$ adalah bilangan yang tertera pada kolom $t$ untuk baris Penguasaan Kosakata dalam Tabel 3. Sedangkan nilai $t_{\text {tabel }}$ adalah nilai tabel distribusi $t$ untuk taraf nyata $5 \%$ dengan derajat kepercayaan $(\mathrm{df}=n-2)=38$ dimana $n$ adalah banyaknya responden.

Dari Tabel 3, dapat kita lihat bahwa nilai sig $=0,000$ dan $\mathrm{t}_{\text {hitung }}=3,694$ sedangkan $\mathrm{t}_{\text {tabel }}=$ 1,69. Karena nilai sig $<0,05$ dan $\mathrm{t}_{\text {hitung }}>\mathrm{t}_{\text {tabel }}$ maka $\mathrm{H}_{0}$ ditolak yang berarti terdapat pengaruh yang signifikan variabel $\mathrm{X}$ terhadap variabel terikat $\mathrm{Y}$. Dari hasil pengujian korelasi, pengujian regresi maupun dengan melihat model garis tersebut maka dapat disimpulkan bahwa terdapat pengaruh yang signifikan variabel bebas $\mathrm{X}$ terhadap variabel terikat $\mathrm{Y}$. Untuk menunjukkan besarnya sumbangan penguasaan kosakata siswa terhadap ketrampilannya dalam berbahasa Inggris, maka dilakukan analisis koefisien determinasi parsial yang hasilnya disajikan pada Tabel 4 .

Tabel 4. Koefisien Determinasi Parsial dengan Variabel X (Penguasaan Kosakata) pada Siswa

\begin{tabular}{ccc}
\hline \multirow{2}{*}{ Variabel Independen } & \multicolumn{2}{c}{ Koefisien determinasi } \\
\cline { 2 - 3 } & Sumbangan Mutlak & Sumbangan Efektif \\
\hline $\mathrm{X}$ & 0,253 & 40,22 \\
\hline
\end{tabular}

Hasil pada tabel 4 menunjukkan bahwa sumbangan variabel penguasaan kosakata (X) sebesar 40,22 persen terhadap keterampilan siswa dalam berbahasa Inggris. Hasil ini sesuai dengan sintesis dari beberapa teori yang menyatakan bahwa salah satu kriteria agar dikategorikan sebagai pembicara yang terampil adalah mampu untuk berkomunikasi lisan secara efektif dan efisien. Karena dalam proses berkomunikasi memerlukan kosakata untuk mewakili ide, pesan ataupun gagasan yang akan disampaikan, maka siswa yang memiliki penguasaan kosakata yang baik dapat dipastikan akan lebih mudah dalam berkomunikasi.

Dengan memiliki penguasaan kosakata yang baik, kemampuan berbicara mereka dapat lebih berkembang. Mereka dapat dengan leluasa menyampaikan buah pikiran mereka dengan bahasa asing karena mereka memahami kosakata yang mewakili isi pesan yang akan mereka sampaikan dalam bahasa Inggris. Penguasaan kosakata dalam bahasa Inggris yang baik akan membantu para siswa untuk berbicara dengan terampil. Selanjutnya, siswa yang memiliki perbendaharaan kata yang banyak dapat menyampaikan buah pikiran mereka dengan lebih bebas dan tidak dibatasi oleh ketidaktahuan akan kosakata tertentu. 


\section{Simpulan dan Saran}

\section{Simpulan}

Berdasarkan perhitungan yang telah dilakukan, terbukti bahwa ada korelasi/pengaruh yang signifikan penguasaan kosakata terhadap keterampilan berbicara siswa dalam bahasa Inggris. Hal ini terbukti dari hasil pengujian hipotesis dimana nilai $\operatorname{sig}=0,000$ dan $\mathrm{t}_{\text {hitung }}=3,694$ sedangkan $\mathrm{t}_{\text {tabel }}=1,69$ sehingga nilai sig $<0,05$ dan $\mathrm{t}_{\text {hitung }}>\mathrm{t}_{\text {tabel }}$ yang berarti terdapat pengaruh yang signifikan.

\section{Saran}

1. Para guru/pengajar bahasa Inggris dapat memberikan perhatian dalam memberikan materi, khususnya untuk memperkuat kosakata para siswa dengan menggunakan metode yang menarik dan menyenangkan.

2. Perlu dilakukan penelitian lanjutan mengenai metode yang menarik dan efektif dalam memperkuat kosakata siswa.

\section{Daftar Pustaka}

Arsjad, M. G. dan Mukti, U. S. (1991). Kemampuan Berbicara Bahasa Indonesia. Jakarta: Erlangga.

Chaer, A. (2009). Sintaksis Bahasa Indonesia. Edisi keempat. Jakarta: Gramedia Pustaka Utama.

Djiwandono, S. (1996). Tes Bahasa dalam Pengajaran. Bandung: ITB.

Keraf, G. (2007). Diksi dan Gaya Bahasa. Jakarta: Gramedia.

Nurgiyantoro, B. (1995). Penilaian dalam Pengajaran Bahasa dan Sastra Indonesia. Yogyakarta: BPFE.

Nurgiyantoro, B. (2001). Penelitian dalam Pengajaran Bahasa dan Sastra. Yogyakarta: Pustaka Pelajar.

Pratomo, D. S. dan Astuti, E. Z. (2015). Analisis Regresi dan Korelasi Antara Pengunjung dan Pembeli terhadap Nominal Pembelian di Indomaret Kedungmundu Semarang dengan Metode Kuadrat Terkecil. CyberKU Journal. Universitas Dian Nuswantoro.

Riduwan. (2010). Dasar-Dasar Statistika. Bandung: Alfabeta.

Robbins, S. P. (2000). Teori Organisasi (Terjemahan Yusuf Udaya). Jakarta: Acam.

Slamet, S. Y. (2009). Dasar-dasar Keterampilan Berbahasa Indonesia. Surakarta: LPP UNS dan UNS Press.

Soemarjadi. (2001). Pendidikan Keterampilan. Malang: Universitas Negeri Malang.

Subana, M dan Sunarti. (2000). Strategi Belajar Mengajar Bahasa Indonesia. Bandung: Pustaka Setia.

Sudjana. (2006). Metode Statistika. Edisi kelima. Bandung: Tarsito.

Sudjana. (2006). Teknik Analisis Regresi dan Korelasi. Bandung: Tarsito.

Sugiyono. (2008). Metode Penelitian Kuantitatif, Kualitatif dan R\&D. Bandung: Alfabeta.

Sugiyono. (2010). Statistika untuk Penelitian. Bandung: Alfabeta.

Tarigan, H. G. (2008). Berbicara: Sebagai Suatu Keterampilan Berbahasa. Bandung: Angkasa.

Yunisah, A. (2007). Pengaruh Media Audio Visual terhadap Penguasaan Kosakata Bahasa Indonesia.Yogyakarta: Skripsi FBS-UNY. 